\title{
Seasonal growth and reproductive status of Grateloupia subpectinata (Rhodophyta) on the east coast of Korea
}

\author{
Ratih Ida Adharini ${ }^{1,2}$, Joon Kim¹, Ganesan Kandasamy ${ }^{1}$ and Hyung Geun Kim
}

\begin{abstract}
Reproductive phenological pattern on tetrasporophytes and carposporophytes of Grateloupia subpectinata thalli were observed at Yangyang, on the middle east coast of Korea from January to December 2013. DNA sequences of cox1 gene from 48 selected samples were compared to assure that sample collection is single species, and they were all identical G. subpectinata. Density, length and width of thalli were significantly changed monthly. The maximum of density, length and fresh weight occurred in September, and continuous growth was observed during the autumn and winter. Tetrasporophytes were grown dominantly in October and November, whereas carposporophytes were dominated in September and March. Upright thalli disappeared in June and July and then juveniles were abundant in August. There was a significant difference in length between tetrasporophytes and carposporophytes. These reproductive pattern and seasonality together with phenological data of G. subpectinata would provide valuable information about successful seedling supply for aquaculture of the species in the future.
\end{abstract}

Keywords: Grateloupia subpectinata, Seasonal growth, Tetrasporophyte, Carposporophyte

\section{Background}

The genus of Grateloupia is consumed as a side dish of rice in the east coast of Korea. The price is very high as compared to the other seaweeds such as Undaria and Saccharina. Because of the economical importance of the Grateloupia spp., research on the cultivation techniques of these species should be carried out for mass cultivation in Korea. Grateloupia subpectinata, G. asiatica and G. divaricata are widely distributed along the east coast and Jeju Island (Lee and Kang, 2001; Lee, 2008; Lee et al., 2011). Grateloupia spp. have been known as invasive algae in North America and Europe possibly due to global shippings and mariculture activities (Harlin and Villalard-Bohnsack, 2001; Verlaque, 2001; Gavio and Fredericq, 2002; Verlaque et al., 2005; Wilkes et al., 2006; Mathieson et al., 2008) and supposed to have a wide range of adaptability.

Spatial and temporal variations of seaweed populations are influenced by differences in physical and biological factors (Schiel and Foster, 2006; Wichachucherd et al.,

\footnotetext{
* Correspondence: kimhg@gwnu.ac.kr

${ }^{1}$ Department of Marine Bioscience, Gangneung-Wonju National University, 7

Jukheongil, Gangneung City, Gangwon Province 210-702, Korea

Full list of author information is available at the end of the article
}

2010). Fluctuations in temperature, wind speed and upwelling index are related with annual variations in relative abundance of marine algae (Hemández-Guerrero et al., 2000). Beside the density, red algae have alternating life stages of gametophytes and sporophytes. Grateloupia is also one of them, and its life stages are isomorphic (Kawaguchi et al., 2001). However, those two life stages may respond differently to environmental factors. We investigated those differences with monthly survey throughout the year.

Studies on phenology as well as complex interactions between environmental factors and changes in abundance over seasons would be helpful for the management of this seaweed resource. These information may indicate when it is good timing for cultivation and also determine an ideal period for harvesting (Adharini and Kim, 2014; May-Lin and Ching-Lee, 2013). Therefore, the results of this research will be applied for the mariculture of Grateloupia.

\section{Methods \\ Environmental conditions and sampling}

The study was carried out at Namae, Yangyang-gun in the eastern coast of Korea $\left(38^{\circ} 4^{\prime} \mathrm{N}, 128^{\circ} 37^{\prime} \mathrm{E}\right)$. Namae coast is the intertidal zone which has rocky substrate 


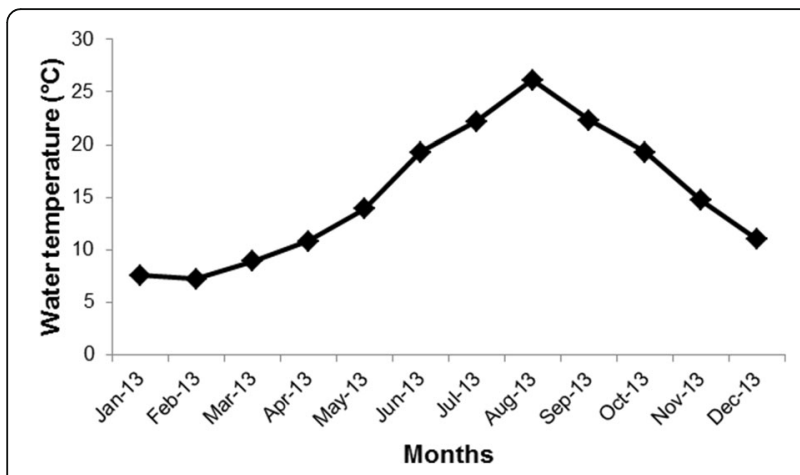

Fig. 1 Water temperature at Yangyang, Korea

and some parts covered by sands. Thalli of G. subpectinata were collected with holdfast from January to December 2013. Three quadrats of $50 \mathrm{~cm} \mathrm{x} 50 \mathrm{~cm}$ were placed randomly to study population density. Seaweed samples were kept and stored into a cooler until carried to laboratory. Water temperature data were obtained from the database of Korea Oceanographic Data Center (KODC, 2014) in monthly averages of meteorological observations in 2013 (Fig. 1).

\section{Sample measurements}

We analyzed cox1 gene from our monthly collections of $G$. subpectinata throughout the year. Specimens were pressed onto herbarium sheets and subsamples were dehydrated in silica gel for DNA analysis. DNA extraction, PCR amplification, and sequencing were performed as described in Boo et al. (2013). The primers used for amplifying and sequencing were COXI43F and COXI1549R for cox1 (Geraldino et al., 2006). Phylogeny of cox 1 was reconstructed using neighbor joining method, using Grateloupia angustata, G. elliptica and G. lanceolata as outgroups (Fig. 2).

Fresh weight and total length of thalli and the width of main axis were measured. Samples were then checked for the reproductive status. Tetraposorophytes and carposporophytes were grouped and measured lengths of main axis, first branch, second branch and third branch of each thallus (Fig. 3).

\section{Statistical analysis}

An estimation of the density, length of thalli, fresh weight, width and reproductive status in every month were presented graphically (Fig. 4). Comparison between tetrasporophytes and carposporophytes on total length, fresh

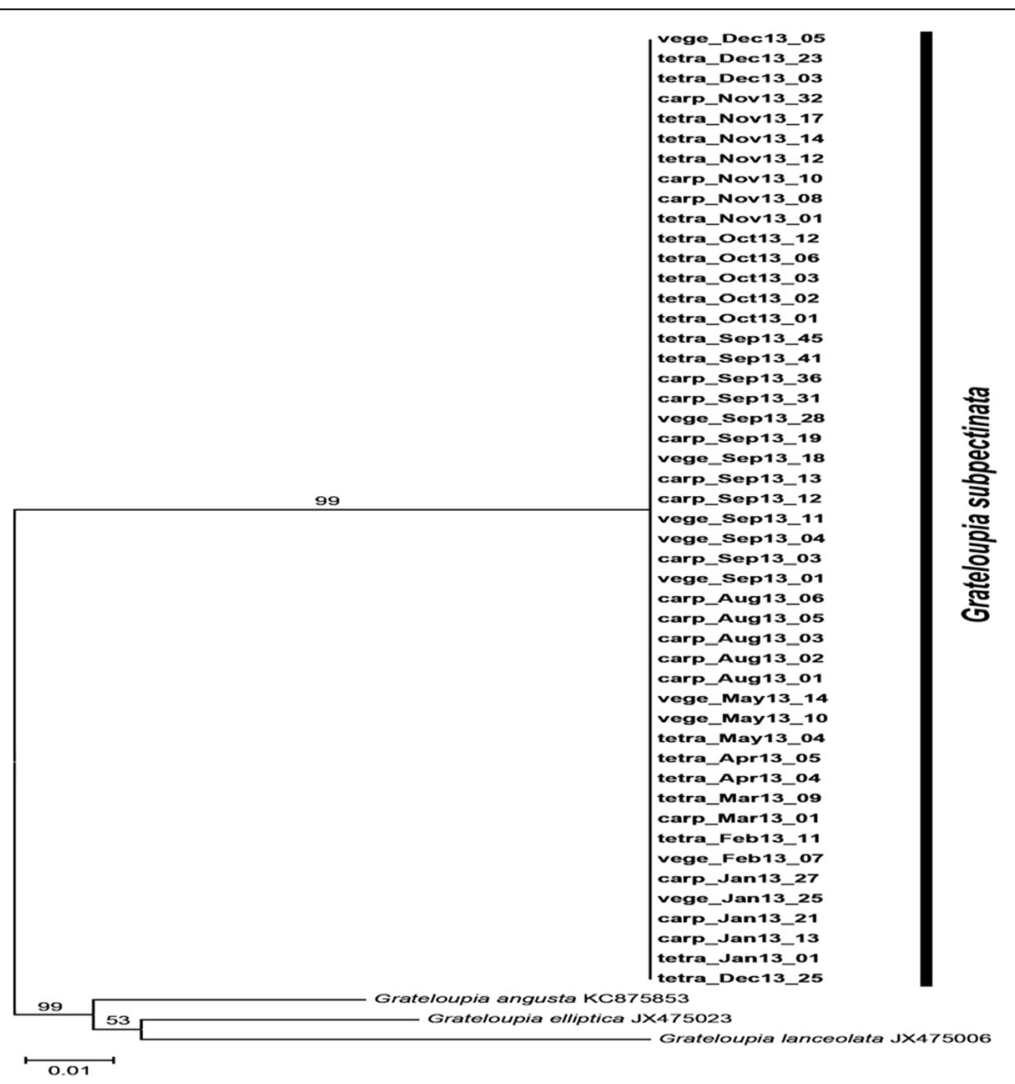

Fig. 2 DNA sequences of $\operatorname{cox} 1$ gene 




Fig. 3 Thallus measurement. a: Total length $(\mathrm{cm})$ of a thallus, from the holdfast to the tip of the longest point. $\mathbf{b}$ : Length $(\mathrm{cm})$ of the main axis, from the holdfast to the tip of the main axis. $\mathbf{c}$ : Length $(\mathrm{cm})$ of the first branch, from the basal to the tip of the first branch. $\mathbf{d}$ : Length $(\mathrm{cm})$ of a second branch, from the basal to the tip of a second branch. e: Length $(\mathrm{cm})$ of a third branch, from the basal to the tip of a third branch. $\mathbf{f}$ : Width $(\mathrm{mm})$

weight and width of thalli were analyzed by $t$-test (MannWhitney Rank Sum Test) with significance level of 0.05. Statistical analysis was performed using the Sigma Plot 11 program.

\section{Results}

\section{Seasonal growth of Grateloupia subpectinata at}

\section{Yangyang, Korea}

We generated 48 cox 1 sequences from sample monthly collections except June and July when erect thalli disappeared. All cox 1 sequences were identical with each other.
Our cox 1 sequences from cystocarpic and tetrasporangial fronds were exactly the same with those from vegetative fronds (Fig. 2).

There were distinctive monthly changes in density, total length, and width of fronds (Table 1). Frond density was the greatest in September (41 individuals $/ 0.25 \mathrm{~m}^{2}$ ) and it was high between autumn and winter. However, it was decreased from February to July when upright fronds were necrotic (Fig. 4a). Fronds grew well between September and February and they reached up to $10 \mathrm{~cm}$ in length. In March, main axis of many fronds were broken off, showing decrease in average frond lengths. After upright thalli were disappeared in June and July, they started forming juvenile thalli again in August and also became abundant (Fig. 4a, b). The highest fresh weight per individual frond was observed in September (2.34 g/ind, Fig. 4c). The widest thalli was observed in November $(3.43 \mathrm{~mm}$, Fig. 4d) and the spore maturation also was on peak in that month (Fig. 5).

Seasonal temperature was varied from $7.8-8.8{ }^{\circ} \mathrm{C}$ in winter (Dec-Feb), $9.3-18{ }^{\circ} \mathrm{C}$ in spring (Mar-May), $20-30{ }^{\circ} \mathrm{C}$ in summer (June-Aug) and $22.5{ }^{\circ} \mathrm{C}$ to $15.7^{\circ} \mathrm{C}$ in fall (Sep-Nov) (Fig. 1).

\section{Reproductive status of Grateloupia subpectinata}

Tetrasporophytes bearing tetrasporangia were abundant in October, November and May although they were observed throughout the year except in June and July. Meanwhile, carposporophytes were abundant in September and March. Juvenile thalli grew throughout the year, particularly abundant in August, February and April (Fig. 5).
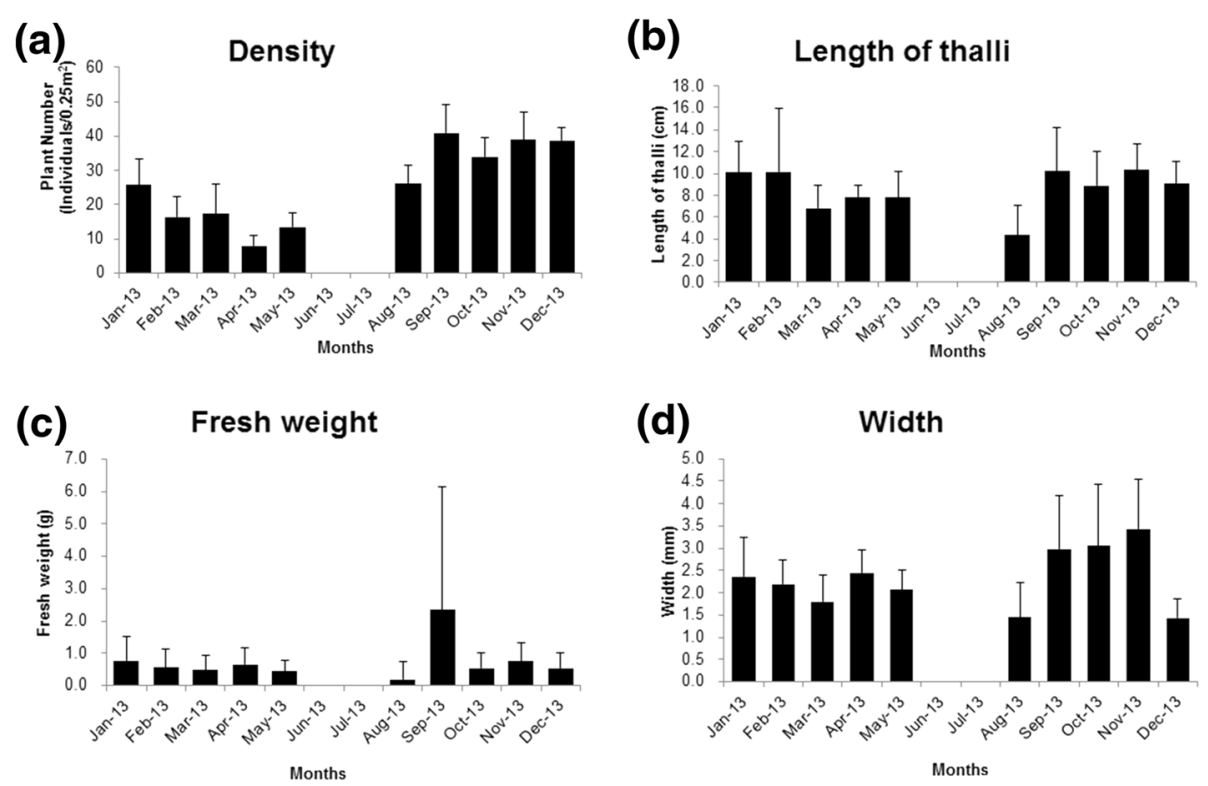

Fig. 4 Changes in the morphological characteristics of G. subpectinata. (a) density, (b) length of thalli, (c) fresh weight, and (d) width of thalli. Numbers of analysed samples are vary monthly from 0 to 45 (See Table 1) 
Table 1 Monthly variation in total length, fresh weight and width of G. subpectinata thalli

\begin{tabular}{llll}
\hline Month & Total length $(\mathrm{cm})$ & Fresh weight $(\mathrm{g})$ & Width $(\mathrm{mm})$ \\
\hline Jan $(n=30)$ & $10.1 \pm 2.9$ & $0.8 \pm 0.8$ & $2.4 \pm 0.9$ \\
Feb $(n=26)$ & $10.2 \pm 5.8$ & $0.6 \pm 0.6$ & $2.2 \pm 0.5$ \\
Mar $(n=26)$ & $6.9 \pm 2.1$ & $0.5 \pm 0.5$ & $1.8 \pm 0.6$ \\
Apr $(n=11)$ & $7.9 \pm 1.0$ & $0.7 \pm 0.5$ & $2.5 \pm 0.5$ \\
May $(n=24)$ & $7.8 \pm 2.4$ & $0.4 \pm 0.4$ & $2.1 \pm 0.5$ \\
Jun $(n=0)$ & NA & NA & NA \\
Jul $(n=0)$ & NA & NA & NA \\
Aug $(n=40)$ & $4.4 \pm 0.6$ & $0.2 \pm 0.2$ & $1.4 \pm 0.3$ \\
Sep $(n=45)$ & $10.2 \pm 1.7$ & $2.3 \pm 3.8$ & $3.0 \pm 0.8$ \\
Oct $(n=30)$ & $8.4 \pm 2.6$ & $0.5 \pm 0.3$ & $3.2 \pm 0.6$ \\
Nov $(n=30)$ & $10.3 \pm 1.6$ & $0.8 \pm 0.2$ & $3.3 \pm 0.4$ \\
\hline
\end{tabular}

Values are mean \pm standard error (NA Not available)

Carposporophytes showed a high variation of length due to seasonality. Carposporophytes in January had long and tufty type because they had long main axes and first branches, and they were wide. In February they grew longer and tufty because they also had third branches. However, in March many thalli were fragmented in main axis and just remained long in the first branches. In April to July carposporophytes disappeared, they were shown again in August with long and tufty type. In September, carposporophytes were abundant which had two types of thalli. They were long, big, tufty carposporophyte type and short simple thalli carposporophyte type. These types were still abundant and available until November. However, in December, long and tufty thalli were fragmented on main axis which caused shorter in length (Table 2).
Tetrasporophytes were collected throughout the year. Seasonal variation gave a significant effect on their phenology. In January, tetrasporophytes had long but simple thalli. However, in February and March, some thalli were fragmented in main axis and some were still as juvenile stage. In April and May, juvenile thalli grew longer which have long main axis with, and short thalli but have tufty branches. In June and July, thalli were disappeared, subsequently in August thalli had long and simple branches. Tetrasporophytes also grew in two types in September to November, which were long and tufty branches type and short simple thalli type. However, many thalli were fragmented in main axis in December which caused shorter main axis, but they still have tufty branches in basal portion (Table 3).

The length of sporophytes main axis is longer than that of carposporophytes (Table 4). However, carposporophytes

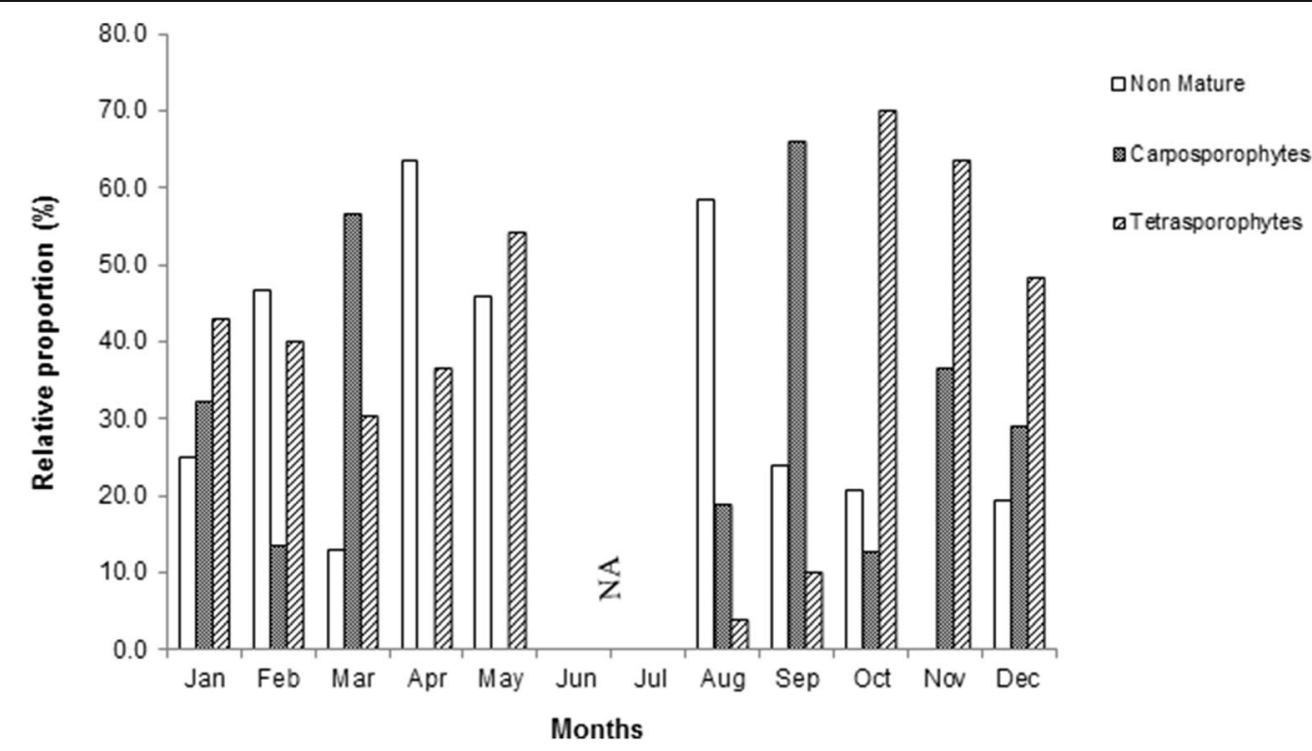

Fig. 5 Seasonal variation in reproductive status of G. subpectinata at Yangyang, Korea. (NA: Not Available) 
Table 2 Variations in phenology of carposporophytes at Yangyang, Korea

\begin{tabular}{|c|c|c|c|c|c|}
\hline Months & $\begin{array}{l}\text { Length of main } \\
\text { axis }(\mathrm{cm})\end{array}$ & $\begin{array}{l}\text { Length of } 1^{\text {st }} \\
\text { branches }(\mathrm{cm})\end{array}$ & $\begin{array}{l}\text { Length of } 2^{\text {nd }} \\
\text { branches }(\mathrm{cm})\end{array}$ & $\begin{array}{l}\text { Length of } 3^{\text {rd }} \\
\text { branches }(\mathrm{cm})\end{array}$ & Types of thalli \\
\hline $\operatorname{Jan} 20^{\text {th }}$ & $7.4 \pm 3.04$ & $7.3 \pm 4.22$ & $0.5 \pm 0.33$ & - & Long and tufty \\
\hline Feb $21^{\text {st }}$ & $12.4 \pm 6.86$ & $2.5 \pm 2.82$ & $2.65 \pm 3.32$ & $0.5 \pm 0.12$ & Long and tufty \\
\hline Mar $12^{\text {nd }}$ & $4.5 \pm 2.57$ & $4.7 \pm 3.46$ & $1.0 \pm 1.14$ & - & Short and tufty (fragmented) \\
\hline Apr $15^{\text {th }}$ & - & - & - & - & - \\
\hline May $23^{\text {rd }}$ & - & - & - & - & - \\
\hline Jun $20^{\text {th }}$ & - & - & - & - & - \\
\hline Jul $19^{\text {th }}$ & - & - & - & - & - \\
\hline Aug $14^{\text {th }}$ & $8.0 \pm 3.20$ & $5.1 \pm 1.92$ & $1.8 \pm 1.28$ & $0.9 \pm 0.42$ & Long and tufty \\
\hline Sept $18^{\text {th }}$ & $4.9 \pm 6.87$ & $3.2 \pm 3.31$ & $1.1 \pm 1.73$ & $0.2 \pm 1.36$ & Long tufty; and short simple thalli \\
\hline Oct $22^{\text {nd }}$ & $4.7 \pm 2.02$ & $2.9 \pm 1.02$ & $1.5 \pm 0.86$ & - & Long tufty; and short simple thalli \\
\hline Nov $22^{\text {nd }}$ & $4.1 \pm 1.26$ & $4.9 \pm 1.48$ & $0.95 \pm 0.41$ & - & Long tufty; and short simple thalli \\
\hline $\operatorname{Dec} 27^{\text {th }}$ & $3.4 \pm 2.07$ & $5.2 \pm 1.75$ & $0.8 \pm 0.58$ & - & Short tufty thalli (fragmented) \\
\hline
\end{tabular}

Values are mean \pm standard error

had longer first and second branches than tetrasporophytes. The longest main axis was observed in January, because thalli grew simple without third branches. The longest first branch was occurred in December, but main axis were shorter. Second branches were longest in February, while third branches were longest in April. On the other hand, carposporophytes were grown more axially and shown longer first and second branches than tetrasporophytes.

There was a significant difference on total length between carposporophytes and tetrasporopytes $(p=0.04)$. Fresh weight and width of thalli shown no significant difference between tetrasporophytes and carposporophytes.

\section{Discussion}

We successfully analyzed cox1 (1000 bp) from 48 specimens collected during our study despite some difficulties in DNA extraction and amplification from Grateloupia. As expected from previous $r b c \mathrm{~L}$ study of G. subpectinata (Lee et al., 2009), our cox 1 tree confirmed that all collected samples belonged to G. subpectinata. Genetic uniformity in all monthly collections suggests that Namae population of G. subpectinata may be derived from a single genetic source.

Higher density of Grateloupia was occurred from September to November and persisted until the beginning of winter season $\left(22.5\right.$ to $\left.7.8^{\circ} \mathrm{C}\right)$. It was recorded that the growth of thalli were maximum at high temperature during summer season. Moreover, from September until November, thalli appeared to have different morphological types. Thalli grew abundant and looked healthy when temperature decreased. In the contrary, Perfeto (1998) reported that $G$. doryphora grew slowly in winter season and then began to grow in spring and showed maximal

Table 3 Variations in phenology of tetrasporophytes at Yangyang, Korea

\begin{tabular}{|c|c|c|c|c|c|}
\hline Months & $\begin{array}{l}\text { Length of main } \\
\text { axis }(\mathrm{cm})\end{array}$ & $\begin{array}{l}\text { Length of } 1^{\text {st }} \\
\text { branch }(\mathrm{cm})\end{array}$ & $\begin{array}{l}\text { Length of } 2^{\text {nd }} \\
\text { branches }(\mathrm{cm})\end{array}$ & $\begin{array}{l}\text { Length of } 3^{\text {rd }} \\
\text { branches }(\mathrm{cm})\end{array}$ & Types of thalli \\
\hline Jan $20^{\text {th }}$ & $8.1 \pm 2.78$ & $1.2 \pm 1.11$ & $0.2 \pm 0.12$ & - & Long with simple thalli \\
\hline Feb $21^{\text {st }}$ & $3.7 \pm 1.04$ & $2.6 \pm 1.25$ & $1.7 \pm 1.25$ & - & Short main axis, longer $1^{\text {st }}$ and $2^{\text {nd }}$ branches \\
\hline Mar $12^{\text {nd }}$ & $1.5 \pm 1.05$ & $3.8 \pm 0.76$ & $0.5 \pm 0.28$ & - & Short main axis, longer $1^{\text {st }}$ and $2^{\text {nd }}$ branches \\
\hline Apr $15^{\text {th }}$ & 2.67 & 3.06 & 0.93 & $0.2 \pm 0.28$ & Short and tufty banches \\
\hline May $23^{\text {rd }}$ & 9 & 1.17 & 0.65 & $0.1 \pm 0.15$ & Long and short branches \\
\hline Jun $20^{\text {th }}$ & - & - & - & - & - \\
\hline Jul $19^{\text {th }}$ & - & - & - & - & - \\
\hline Aug $14^{\text {th }}$ & $5.8 \pm 2.47$ & $3.0 \pm 1.69$ & $0.3 \pm 1.65$ & - & Long main axis, simple branches \\
\hline Sept $18^{\text {th }}$ & $10.2 \pm 2.08$ & $4.0 \pm 1.00$ & $0.3 \pm 0.2$ & - & Long main axis, simple branches \\
\hline Oct $22^{\text {nd }}$ & $8.2 \pm 2.49$ & $5.8 \pm 2.02$ & $2.0 \pm 0.47$ & $0.6 \pm 0.48$ & Long and short main axis, and tufty branches (irregular) \\
\hline Nov $22^{\text {nd }}$ & $8.9 \pm 2.82$ & $4.5 \pm 2.09$ & $1.3 \pm 1.49$ & $0.7 \pm 0.32$ & Long and short main axis, and tufty branches (irregular) \\
\hline $\operatorname{Dec} 27^{\text {th }}$ & $2.9 \pm 1.33$ & $5.7 \pm 1.90$ & $2.9 \pm 1.68$ & $0.6 \pm 0.11$ & Short and tufty (irregular) \\
\hline
\end{tabular}


Table 4 The phenology of G. subpectinata thalli

\begin{tabular}{|c|c|c|c|c|}
\hline Parameter & Main axis $(\mathrm{cm})$ & First branches $(\mathrm{cm})$ & Second branches $(\mathrm{cm})$ & Third branches $(\mathrm{cm})$ \\
\hline \multicolumn{5}{|l|}{ Reproductive status } \\
\hline Carposporophytes & 5.0 & 4.1 & 1.1 & 0.05 \\
\hline Tetrasporophytes & 6.7 & 3.7 & 1.0 & 0.05 \\
\hline \multicolumn{5}{|l|}{ Months } \\
\hline Jan $20^{\text {th }}, 2013$ & 7.759 & 3.105 & 0.123 & 0.000 \\
\hline Feb 21 ${ }^{\text {st }}, 2013$ & 5.490 & 2.560 & 2.060 & 0.100 \\
\hline Mar $12^{\text {nd }} 2013$ & 3.413 & 4.713 & 0.663 & 0.000 \\
\hline Apr $15^{\text {th }} 2013$ & 5.120 & 3.400 & 1.859 & 0.170 \\
\hline May $23^{\text {rd }} 2013$ & 6.750 & 0.875 & 0.320 & 0.025 \\
\hline Jun $20^{\text {th }} 2013$ & 0.000 & 0.000 & 0.000 & 0.000 \\
\hline Jul $19^{\text {th }} 2013$ & 0.000 & 0.000 & 0.000 & 0.000 \\
\hline Aug $14^{\text {th }} 2013$ & 6.078 & 3.422 & 1.411 & 0.167 \\
\hline Sep $18^{\text {th }} 2013$ & 5.712 & 3.308 & 0.869 & 0.027 \\
\hline Oct $19^{\text {th }} 2013$ & 6.952 & 5.114 & 1.892 & 0.062 \\
\hline Nov $22^{\text {nd }} 2013$ & 6.796 & 4.689 & 0.607 & 0.025 \\
\hline Dec 27 2013 & 3.153 & 5.482 & 1.859 & 0.100 \\
\hline
\end{tabular}

growth rate in summer. Growing season is different from species to species although they belongs to the same genus Grateloupia. Density began to decrease in February to May before thalli disappeared in June and July when summer season begins. It is suggested that in summer time they changed into crust form as a survival strategy to overcome high water temperature $\left(20-25.3{ }^{\circ} \mathrm{C}\right)$. This phenomenon was also suggested by Harlin and VillalardBohnsack (2001) that G. doryphora changed to crustose form during unfavourable conditions as a strategy for survival. While, Ilma et al. (1995) suggested that crust form is an adaptation for survival when grazing pressure is high. High temperature also caused disappearance of gametophytes in Bangiales (Sheath and Cole 1984).

Density of G. subpectinata was decreased with high temperature while the abundance of Sargassum thunbergii was increased. It may be due to the competition for nutrients and sunlight. This phenomenon also occurred in Sarcothalia crispata which declined in density and biomass associated with unusual increase in density of G. doryphora (Otaiza et al., 2001). In June and July, Yangyang had more frequency of raining that affected low salinity and sedimentation on the rocky substrate. While, Eriksson and Johansson (2003) suggested that sedimentation affected attachment and survival of spores in Fucus vesiculosus. This phenomenon also occurred in Padina boryana which caused no recruitment in rainy season (Wichachucherd et al., 2010). In August, when water temperature reached the highest $\left(30{ }^{\circ} \mathrm{C}\right)$, juvenile upright thalli of G. subpectinata were grown abundantly. It is suggested that water temperature of $25-30{ }^{\circ} \mathrm{C}$ is the optimum to trigger crusts for generating juvenile upright thalli. Grazers may act to disturb the density of sporeling (Griffin et al., 1999), however, grazing was not shown for G. subpectinata in this study.

The length and fresh weight of G. subpectinata thalli were highest in September when water temperature was $22.3^{\circ} \mathrm{C}$ at Yangyang. Fresh weight were also peaked in September, thalli contained matured spores and were grown long, big and tufty. However, length of thalli became shorter after the high length period. It is suggested that after thalli get the high length and matured, those thalli were getting weak which caused fragmented in main axis.

Carposporophytes were abundant during winter season whereas the tetrasporophytes were available around the year except in June and July. Thus, thalli which were found mostly are in sporophytic stage than in gametophytic stage. The dominance of tetrasporophytes were also found in Gracilaria gracilis in Thau Lagoon in France (Marinho-Soriano et al, 1998), Gelidium pussilum in Songkhla, Thailand (Prathep et al., 2009) and G. gracilis from north-eastern Sicily, Italy (Polifrone et al., 2006). However, tetrasporophytes were abundant in October and November after carposporophytes grew abundant in September. It is suggested that carpospores had higher survivorship and then resulted higher abundance of tetrasporophytes. This phenomenon also occurred in G. gracilis which reported that diploid phase showed a higher resistance to environmental stress than haploid (Polifrone et al., 2006). Destombe et al. (1989) also mentioned that G. gracilis at juvenile stage of diploid had twice the survival rate than haploids. Meanwhile, tetraspores of Gracilaria skottsbergiiwere better adapted for growth in winter and carpospores to spring and summer, thus diploidic tetrasporophytic plants were more abundant in summer (Westermeier et al, 1999). 
Seasonal variation gave significant effects on phenology of carposporophytes and tetrasporophytes of G. subpectinata at Yangyang. It is suggested that it was a kind of survivorship strategy for adapting the seasonally variating conditions like water temperature, photoperiod and wave hight. In January and February, carposporophytes grew with long main axis and tufty branches. However, in March when matured carposporophytes were grown abundantly, they were fragmented in main axis. Besides the effect of high waves, it may be also a kind of reproductive strategy to spread the carpospores into a wider space by the drifting of fragmented thalli. This phenomenon also reported in Sargassum muticum and its genus. At the end of reproductive period, fertile laterals were detached and would float to colonize distant area (Stiger and Payri 1999; Plouguerne et al., 2006). Dispersal strategy also occurred in Turbinaria ornata, when there was greater wave motion, mature plants with high number of receptacles would be driven away to increase the dispersal range (Prathep et al, 2007).

In August, carposporophytes of G. subpectinata at Yangyang grew with long main axis and tufty branches. Meanwhile in September, there were two kinds of carposporophyte types: 1) carposporophytes which have long and tufty thalli; 2) carposporophytes which have short and simple thalli. These two kinds of carposporophyte types were available from September to November. Meanwhile, tetrasporophytes grew with long and simple thalli in January. Subsequently, in February and March thalli of tetrasporophytes were decreased in the length of main axis. However, they still had long first and second branches. It may be some kind of survival strategy to respond defferent environmental conditions. The difference in phenology throughout the year also occurred in Sarcothalia crispata, that changed in abundance along season also have different types of fronds (Otaiza et al, 2001). Meanwhile, Prathep et al. (2007) suggested that shorter frond length or blade and fewer number of blades which was found in shore, can be assumed as acclimations to resist the higher energy wave force by minimizing thalli became fragmented. Instead of adaptation to the environmental changes, seaweeds sometimes use them such as the application of high waves to fragment and spread their fertile thalli in a wider place as a reproduction strategy. Carposporophytes have relationship between length and fresh weight, length and width, fresh weight and width higher than tetrasporophytes. It is suggested that tetrasporophyte have type of growth by elongating main axis, while carposporophyte have type of growth by elongating branches aside.

\section{Conclusions}

Grateloupia subpectinata showed various ratio of carposporophytes and tetrasporophytes. Tetrasporophytes were more abundant than carposporophytes in most of months except March, August and September. This is due to different growth and survivorship of haploid and diploid each month. Fresh weight of this alga showed high value in September. We can collect tetrasporophytes all around a year except June and July for seedling production, an also carposporophytes in September and March if we need diploid seeding. Preferred cultivation season of G. subpectinata will be good September to March of the next year. Base on those informations, we hope to easily develop mass culture methods of this alga in the future.

\section{Competing interests}

The authors declare that they have no competing interests.

\section{Authors' contributions}

RA carried out the analysis which plant is gametophyte and sporophyte in reprodcutive status (including sampling, making dry species, observing material under microscope) and drafted the manuscript. JK participated sampled in field and observed under microscope each plant to identify collected samples. GK participated in sampling and observing Grateloupia plants in every month in lab and field. HK carried out design and coordination of this study which was conducted plan of this study, sampled in field, analysed data and approved the manuscript. All authors read and approved the final manuscript.

\section{Acknowledgement}

This research was supported by 'Development of Mass Production of Grateloupia (2012 2014)' project funded by the Ministry of Oceans and Fisheries. And also this work was financially supported by the R\&D project of "Development of Desalination Plant using Ocean Thermal Energy (2014 2015)" supported by the Korea Research Institute of Ships \& Ocean Engineering.

\section{Author details}

${ }^{1}$ Department of Marine Bioscience, Gangneung-Wonju National University, 7 Jukheongil, Gangneung City, Gangwon Province 210-702, Korea. ${ }^{2}$ Fisheries Department of Faculty Agriculture, Gadjah Mada University, Jogjakarta, Indonesia.

Received: 9 April 2016 Accepted: 20 April 2016

Published online: 12 May 2016

\section{References}

Adharini Rl, Kim HG. Developmental pattern of crust into upright thalli of Grateloupia asiatica (Halymeniaceae, Rhodophyta). J Appl Phycol. 2014;26: 1911-8.

Boo GH, Park JK, Boo SM. Gelidiophycus (Gelidiales, Rhodophyta): a new genus of marine algae from East Asia. Taxon. 2013;62:1105-16.

Destombe C, Valero M, Vernet P, Couvet D. What controls haploid-diploid ratio in the red alga, Gracilaria verrucosa? J Evol Biol. 1989;2:317-38.

Eriksson BK, Johansson G. Sedimentation reduces recruitment success of Fucus vesiculosus (Phacophyceae) in the Baltic Sea. Eur J Phycol. 2003;38:217-22.

Gavio B, Frederica S. Grateloupia turuturu (Halymeniaceae, Rhodophyta) is the correct name of the non-native species in the Atlantic known as Grateloupia doryphora. Eur J Phycol. 2002;37:349-59.

Geraldino PJL, Yang EC, Boo SM. Morphology and molecular phylogeny of Hypnea flexicaulis (Gigartinales, Rhodophyta) from Korea. Algae. 2006;21:417-23.

Griffin N, Bolton J, Anderson R. The effects of a simulated harvest on Porphyra (Bangiales, Rhodophyta) in South Africa. Hydrobiologia. 1999;398(399):183-9.

Harlin MM, Villalard-Bohnsack M. Seasonal dynamics and recruitment strategies of the invasive seaweed Grateloupia doryphora (Halymeniaceae, Rhodophyta) in Narraganset Bay and Rhode Island Sound, Rhode Island, USA. Phycologia. 2001:40:468-74.

Hemández-Guerrero CJ, Casas-Valdez M, Ortega-García S, Hemández-Vazquez S. Effect of climatic variation on the relative abundance of the red alga Gelidium robustum in Baja California Sur, Mexico. J Appl Phycol. 2000;12:177-83.

IIma M, Kinoshita T, Kawaguchi S, Migita S. Cultivation of Grateloupia acuminata (Halymeniaceae, Rhodophyta) by regeneration from cut fragment of basal crust and upright thalli. J Appl Phycol. 1995;7:583-8. 
Kawaguchi S, Wang WH, Horiguchi T, Sartoni G, Masuda M. A comparative study of the red algae Grateloupia filicina (Halymeniaceae) from the Northwestern Pacific and Mediterranean with the description of Grateloupia asiatica, sp. nov. J Phycol. 2001;37:433-42

KODC, 2014. Korea Oceanographic Data Center. http://kodc.nifs.go.kr/ page?id=eng_index. Access 02 Jan 2014

Lee YP. Marine Algae of Jeju. Seoul: Academic Publication; 2008. p. 477.

Lee YP, Kang SY. A Catalogue of the seaweeds in Korea. Jeju: Jeju National University Press; 2001. p. 662.

Lee Jl, Kim HG, Hwang IK, Geraldino PJL, Boo SM. Molecular classification of Grateloupia (Rhodophyta) from Korea. Algae. 2009;24:231-8.

Lee Jl, Hwang IK, Park JK, Kim HG. Seasonal growth of Grateloupia asiatica and G. divaricata (Rhodophyta). Kor J Nat Conser. 2011;5:7-16.

Marinho-Soriano E, Laugier T, De Casabianca ML. Reproductive strategy of two Gracilaria species, G. bursa-pastoris and G. gracilis, in Mediterranean Lagoon (Thau, France). Bot Marina. 1998;41:559-64.

Mathieson AC, Dawes CJ, Pederson J, Gladych RA, Carlton JT. The Asian red seaweed Grateloupia turuturu (Rhodophyta) invades the Gulf of Maine. Biol Invasions. 2008;10:985-8.

May-Lin BY, Ching-Lee W. Seasonal growth rate of Sargassum species at Teluk Kemang, Port Dickson, Malaysia. J Appl Phycol. 2013;25:805-14.

Otaiza RD, Abades SR, Brante AJ. Seasonal changes in abundance and shifts in dominance of life history stages of the carrageenophyte Sarcothalia crispata (Rhodophyta, Gigartinales) in south-central Chile. J Appl Phycol. 2001;13:161-71.

Perfeto PNM. Relation between chemical composition of Grateloupia doryphora (Montagne) Howe, Gymnogongrus griffithsiae (Turner) Martius, and abiotic parameters. Acta Bot Bras. 1998;12:77-88.

Plouguerne E, Lann KL, Connan S, Jechoux G, Deslandes E, Stiger-Pouvreau V. Spatial and seasonal variation in density, reproductive status, length and phenolic content of the invasive brown macroalga Sargassum muticum (Yendo) Frensholt along the coast of Western Brittany (France). Aquat Bot. 2006;85:337-44.

Polifrone M, Masi FD, Gargiulo GM. Alternative pathways in the life history of Gracilaria gracilis (Gracilariales, Rhodophyta) from north-eastern Sicily (Italy). Aquaculture. 2006;261:1003-13.

Prathep A, Wichachucherd B, Thongroy P. Spatial and temporal variation in density and thallus morphology of Turbinaria ornata in Thailand. Aquat Bot. 2007;86:132-8.

Prathep A, Lewmanomont K, Buapet P. Effects of wave exposure on population and reproductive phenology of an algal turf, Gelidium pusillum (Gelidiales, Rhodophyta), Songkhla, Thailand. Aquat Bot. 2009;90:179-83.

Schiel DR, Foster MS. The population biology of large brown seaweeds: ecological consequences of multiphase life histories in dynamic coastal environments. Annu Ref Ecol Syst. 2006;37:343-72.

Sheath RG, Cole KM. Systematics of Bangia (Rhodophyta) in North America. I. Biogeographic trends in morphology. Phycologia. 1984;23:383-96.

Stiger V, Payri CE. Spatial and temporal patterns of settlement of the brown macroalgae Turbinaria ornate and Sargassum mangarevense in a coral reef on Tahiti. Mar Ecol Prog Ser. 1999;191:91-100.

Verlaque M. Checklist of the macroalgae of Thau Lagoon (Hérault, France), a hot spot of marine species introduction in Europe. Oceanol Acta. 2001;24:29-49.

Verlaque M, Brannock PM, Komatsu T, Villalard-Bohnsack M, Marston M. The genus Grateloupia C. Agardh (Halymeniaceae, Rhodophyta) in the Thau Lagoon (France, Mediterranean): a case study of marine plurispecific introductions. Phycologia. 2005;44:477-96.

Westermeier R, Aguilar A, Sigel J, Quintanilla J, Morales J. Biological basis for the management of Gigartina skottsbergii (Gigartinales, Rhodophyta) in southern Chile. Hydrobiologia. 1999;398(399):137-47.

Wichachucherd B, Liddle LB, Prathep A. Population structure, recruitment, and succession of the brown alga, Padina boryana Thivy (Dictyotales, Heterokontophyta), at an exposed shore of Sirinart National Park and a sheltered area of Tang Khen Bay, Phuket Province, Thailand. Aquat Bot. 2010;92:93-8.

Wilkes RJ, Morabito M, Gargiulo GM. Taxonomic considerations of a foliose Grateloupia species from the Straits of Messina. J Appl Phycol. 2006;18:663-9.

\section{Submit your next manuscript to BioMed Central and we will help you at every step:}

- We accept pre-submission inquiries

- Our selector tool helps you to find the most relevant journal

- We provide round the clock customer support

- Convenient online submission

- Thorough peer review

- Inclusion in PubMed and all major indexing services

- Maximum visibility for your research

Submit your manuscript at www.biomedcentral.com/submit
Biomed Central 